\title{
Relationship between Gender Age and Extent Awareness, Knowledge about ICT Tools and Problems Faced in Access and using ICT Tools
}

\author{
G. P. Meena ${ }^{1 *}$ and R. L. Meena ${ }^{2}$ \\ Department of Agricultural Sciences, Jaipur National University, Jaipur (Raj.)-302017, India \\ *Corresponding author
}

\section{A B S T R A C T}

\section{Keywords}

Awareness,

Knowledge, ICT

Tools and Age

Article Info

Accepted:

07 November 2019

Available Online:

10 December 2019
The study was conducted in Azamgarh district of eastern Uttar Pradesh; it included two villages (HirnaiGullygarh and Khalishpur), one medical college and one block (Bilariyaganj Block). A total of 150 respondents including 60 farmers (30 male and 30 female) 70 students ( 35 male and 35 female) and 20 employees (10 male and 10 female) were selected for the study from two villages, two colleges and one block respectively. The male young age group, 42.66 per cent have high awareness and knowledge about ICT tools followed by 16 per cent medium and 8 per cent low awareness and knowledge. Similarly, in male middle age group, 14.66 per cent have high awareness and knowledge about ICT tools followed by 5.33 per cent medium and 4 per cent low awareness and knowledge. Further, in male old age group 5.33 per cent have high awareness and knowledge about ICT tools followed by 2.66 per cent medium and 1.33 per cent low awareness and knowledge. In female young age group, 40 percentage high awareness and knowledge about ICT tools followed by 14.66 per cent medium and 12 per cent low awareness and knowledge. Similarly, in female middle age group, 12 per cent have high awareness and knowledge about ICT tools followed by 5.33 per cent medium and 6.66 per cent low awareness and knowledge. Further, in female old age group 4 per cent have high awareness and knowledge about ICT Tools followed by 4 per cent medium and 1.33 per cent low awareness and knowledge. That the young age group, have high extent of awareness and knowledge about of ICT tools for both male and female but percentage of male $(42.66 \%)$ is comparatively more than female $(40 \%)$. Therefore, it can be concluded that female were facing more problems in accessibility and use of ICT tools in comparison to male.

\section{Introduction}

Access to and use of information and communication technologies (ICTs) are considered important for improving outcomes for different socio-economic groups in the developing world. ICTs are increasingly being used in different aspects of life including healthcare delivery, administration, education and communication (World Bank, 2004). India has been a major hub for rural ICT experiments for more than two decades. Many of these initiatives have clearly revealed the huge potential of new ICTs in improving 
efficiency, effectiveness and reach of rural (as well as urban) service delivery. They also highlight the scope in ensuring the much needed transparency in both government and business. But before we go into the details of new ICTs, it is pertinent to briefly discuss about India's long experience of using some of the traditional ICTs in bringing new technological information on agriculture and other allied subjects to rural communities (Drori and Suk, 2003). Information and Communication Technologies comprise a complex and heterogeneous set of goods, applications and services used to produce, process, distribute and transform information. The ICT sector consists of segments as diverse as telecommunications, television and radio broadcasting, computer hardware, software and services and electronic media (for example, the internet and electronic mail). ICT also have the potential to improve interaction between Governments and citizens, fostering transparency and accountability in governance (Okiy and Ogbomo, 2011). While there is recognition of the potential of ICT as a tool for the promotion of gender equality and the empowerment of women, a "gender divide" has also been identified, reflected in the lower numbers of women accessing and using ICT compared with men. ICT also offers women flexibility in time and space and can be of particular value to women who face social isolation in developing countries. ICTs have immense potential and scope to create new employment opportunities for rural women and make them economically empowered. While ICTs can play an important role in empowering rural women, women's access and use of ICTs and empowerment clearly depends on the vision and operational agenda of the organization applying the ICTs. Therefore, strengthening the ICT initiatives of such organizations can go a long way in empowering rural women. Besides generating locally relevant content and enhancing the capacities of rural women in accessing ICTs, efforts are also needed to bridge the different types of digital divide (rural-urban; menwomen) (Sulaiman et al., 2011).

\section{Materials and Methods}

The plan and structure of investigation so conceived as to obtain answer to research questions. Ex-postfacto research design was followed for conducting the study. The main focus of investigation was to know the extent of awareness, knowledge, extent of utilization and the problems faced during the usage of Information and Communication Technology (ICT) tools.

The study was conducted in the purposively selected Azamgarh district of eastern Uttar Pradesh, it included two villages (Hirnai Gullygarh and Khalishpur), one medical college and one block (Bilariyaganj Block). Selection of the population of the study consisted of male farmers and female farmers, students of Degree College and Medical College and service men and women. A total of 150 respondents including 60 farmers (30 male and 30 female) 70 students ( 35 male and 35 female) and 20 employees (10 male and 10 female) were selected for the study from two villages, two colleges and one block respectively. Independent variables- age, education, marital status, type of family, occupation and dependent variables- Extent of Awareness and Knowledge regarding selected ICT tools, Extent of Accessibility and use of ICT tools, Problems faced in using ICT tools by different gender was selected.

The data were collected with the help of a structured interview schedule constructed for the purpose of study, keeping in view the objectives of the study and the major statistical techniques used in the current study were frequency distributions, percentage and frequency distributions were calculated by 
counting the responses given individuals for a particular question and based on that they are organized to various categories. The percentage was calculated from the obtained frequency distributions.

\section{Results and Discussion}

The data presented in Table 1 shows the distribution of respondents according to their age. Out of the total 75 respondents, huge majority (66.67\%) were from young age group (up to 35 years), followed by middle (24\%) and old age group (9.33\%). It is, therefore, concluded that majority of respondents' belonged to young age group.

The data presented in Table 2 showed that distribution of respondents according to their age. Out of the total 75 respondents, huge majority $(64.00 \%)$ were from young age group (up to 35 years), followed by middle (22.67\%) and old age group (13.33\%). It is, therefore, concluded that majority of respondent's belonged to young age group.

The data of Table 3 show that out of the total respondents of young age group, 42.66 per cent high awareness and knowledge about ICT tools followed by 16 per cent medium and 8 per cent low awareness and knowledge. Similarly, in middle age group, 14.66 per cent have high awareness and knowledge about ICT tools followed by 5.33 per cent medium and 4 per cent low awareness and knowledge.

Further, in old age group 5.33 per cent have high awareness and knowledge about ICT tools followed by 2.66 per cent medium and 1.33 per cent low awareness and knowledge. Therefore, it can be concluded that the highest percentage of awareness and knowledge were found in young aged group. The finding finds support with the work of (Krubu and
Osawaru2011). The data of Table 4 show that out of the total respondents of young age group, 40 percentage having high awareness and knowledge about ICT tools followed by 14.66 per cent medium and 12 per cent low awareness and knowledge. Similarly, in middle age group, 12 per cent have high awareness and knowledge about ICT tools followed by 5.33 per cent medium and 6.66 per cent low awareness and knowledge. Further, in old age group 4 per cent have high awareness and knowledge about ICT tools followed by 4 per cent medium and 1.33 per cent low awareness and knowledge. Therefore, it can be concluded that the highest percentage of awareness and knowledge were found in young aged group. The finding finds support with the work of (Krubu and Osawaru, 2011) and (Agwu et al., 2008).

These figures shows that young age group, have high extent of awareness and knowledge about of ICT tools for both male and female but percentage of male $(42.66 \%)$ is comparatively more than female (40\%) (Table $5)$.

Out of the total respondent of male $(n=75)$ and female $(\mathrm{n}=75)$ total $(\mathrm{N}=150)$, male have high percentage $(58.65 \%)$ of high extent of awareness and knowledge about of ICT tools in comparison to female $(53.33 \%)$. Therefore, it can be concluded that highest percentage of extent of accessibility and use of ICT tools were found in male respondents. The finding finds support with the work of (Nyamba and Mlozi, 2012 and Tata and Paul, 2016).

\section{List of problems faced by respondents}

Lack of knowledge, Financial problem, Restriction by other family members, Ownership by other family members. 
Table.1 Distribution of male respondents according to their age

\begin{tabular}{|c|c|c|c|}
\hline S. No. & Category & \multicolumn{2}{|c|}{ Respondents $(\mathbf{n}=\mathbf{7 5})$} \\
\cline { 3 - 4 } & & Frequency & Percentage \\
\hline $\mathbf{1 .}$ & Young age (up to 35 years) & 50 & $\mathbf{6 6 . 6 7}$ \\
\hline $\mathbf{2 .}$ & Middle age (36 to 50 years) & 18 & $\mathbf{2 4}$ \\
\hline $\mathbf{3 .}$ & Old age (Above 50 years) & 7 & $\mathbf{9 . 3 3}$ \\
\hline & Total & $\mathbf{7 5}$ & $\mathbf{1 0 0 . 0 0}$ \\
\hline
\end{tabular}

Table.2 Distribution of female respondents according to their age

\begin{tabular}{|c|c|c|c|}
\hline \multirow{2}{*}{ S. No. } & Category & \multicolumn{2}{|c|}{ Respondents $(\mathbf{n}=\mathbf{7 5})$} \\
\cline { 3 - 4 } & & Frequency & Percentage \\
\hline $\mathbf{1 .}$ & Young age group (below 35 years) & 48 & $\mathbf{6 4 . 0 0}$ \\
\hline $\mathbf{2 .}$ & Middle age group (36 to 50 years) & 17 & $\mathbf{2 2 . 6 7}$ \\
\hline $\mathbf{3 .}$ & Old age group (Above 50 years) & 10 & $\mathbf{1 3 . 3 3}$ \\
\hline & Total & $\mathbf{7 5}$ & $\mathbf{1 0 0 . 0 0}$ \\
\hline
\end{tabular}

Table.3 Distribution of male respondent based on age and extent awareness and knowledge about ICT tools

\begin{tabular}{|c|c|c|c|c|c|c|c|}
\hline \multirow{3}{*}{ Age } & \multicolumn{7}{|c|}{ Extent of Awareness and Knowledge } \\
\hline & \multicolumn{2}{|c|}{ Low } & \multicolumn{2}{|c|}{ Medium } & \multicolumn{2}{|c|}{ High } & \multirow[t]{2}{*}{ Total } \\
\hline & $\mathrm{f}$ & $\%$ & $\mathrm{~F}$ & $\%$ & $\mathrm{f}$ & $\%$ & \\
\hline Young age (up to 35) & 6 & 8 & 12 & 16 & 32 & 42.66 & 50 \\
\hline Middle age (36-50) & 3 & 4 & 4 & 5.33 & 11 & 14.66 & 18 \\
\hline Old age (above 50) & 4 & 5.33 & 2 & 2.66 & 1 & 1.33 & 7 \\
\hline Total & 13 & 17.33 & 18 & 23.99 & 44 & $\mathbf{5 8 . 6 5}$ & 75 \\
\hline
\end{tabular}

Table.4 Distribution of female respondent based on age and extent awareness and knowledge about ICT tools

\begin{tabular}{|c|c|c|c|c|c|c|c|}
\hline \multirow{2}{*}{ Age } & \multicolumn{8}{|c|}{ Extent of awareness and Knowledge } \\
\cline { 2 - 8 } & \multicolumn{3}{|c|}{ Low } & \multicolumn{2}{c|}{ Medium } & \multicolumn{2}{c|}{ High } \\
\cline { 2 - 7 } & $\mathrm{F}$ & $\%$ & $\mathrm{~F}$ & $\%$ & $\mathrm{~F}$ & $\%$ & \\
\hline Young age (up to 35)) & 9 & 12 & 11 & 14.66 & 30 & 40 & $\mathbf{5 0}$ \\
\hline Middle age (36-50) & 5 & 6.66 & 4 & 5.33 & 9 & 12 & $\mathbf{1 8}$ \\
\hline Old age (Above 50) & 3 & 4 & 3 & 4 & 1 & 1.33 & $\mathbf{7}$ \\
\hline Total & $\mathbf{1 7}$ & $\mathbf{2 2 . 6 6}$ & $\mathbf{1 8}$ & $\mathbf{2 3 . 9 9}$ & $\mathbf{4 0}$ & $\mathbf{5 3 . 3 3}$ & $\mathbf{7 5}$ \\
\hline
\end{tabular}


Table.5 Comparison between male and female on the basis of age and extent awareness and knowledge about ICT tools

\begin{tabular}{|c|c|c|c|c|c|c|}
\hline \multirow{2}{*}{ Category } & \multicolumn{5}{|c|}{ Extent of awareness and knowledge (\%) } \\
\cline { 2 - 7 } & \multicolumn{3}{|c|}{ Male (n=75) } & \multicolumn{3}{c|}{ Female (n=75) } \\
\cline { 2 - 7 } & high & medium & low & low & Medium & high \\
\hline Young age & 8 & 16 & 42.66 & 12 & 14.66 & $\mathbf{4 0}$ \\
\hline Middle age & 4 & 5.33 & 14.66 & 6.66 & 5.33 & $\mathbf{1 2}$ \\
\hline Old age & 5.33 & 2.66 & 1.33 & 4 & 4 & 1.33 \\
\hline Total & $\mathbf{1 7 . 3 3}$ & $\mathbf{2 3 . 9 9}$ & $\mathbf{5 8 . 6 5}$ & $\mathbf{2 2 . 6 6}$ & $\mathbf{2 3 . 9 9}$ & $\mathbf{5 3 . 3 3}$ \\
\hline
\end{tabular}

Table.6 Distribution of male respondents based on their age and Problems faced in Access and using ICT tools

\begin{tabular}{|c|c|c|c|c|c|c|c|}
\hline \multirow[t]{3}{*}{ Age } & \multicolumn{7}{|c|}{ Problems faced in using ICT tools for male } \\
\hline & \multicolumn{2}{|c|}{ Low } & \multicolumn{2}{|c|}{ Medium } & \multicolumn{2}{|c|}{ High } & \multirow[t]{2}{*}{ Total } \\
\hline & $\mathrm{f}$ & $\%$ & $\mathrm{f}$ & $\%$ & $\mathrm{~F}$ & $\%$ & \\
\hline Young age & 31 & 41.33 & 11 & 14.67 & 8 & 10.67 & 50 \\
\hline Middle age & 9 & 12.00 & 5 & 6.67 & 4 & 5.33 & 18 \\
\hline Old age & 1 & 1.33 & 2 & 2.67 & 4 & 5.33 & 7 \\
\hline Total & 41 & 54.67 & 18 & 24.00 & 16 & 21.33 & 75 \\
\hline
\end{tabular}

Table.7 Distribution of female respondents based on their age and Problems faced in Access and using ICT tools

\begin{tabular}{|c|c|c|c|c|c|c|c|}
\hline \multirow{2}{*}{ Age } & \multicolumn{6}{|c|}{ Problems faced in using ICT tools } \\
\cline { 2 - 7 } & \multicolumn{2}{|c|}{ Low } & \multicolumn{2}{c|}{ Medium } & \multicolumn{2}{c|}{ High } & Total \\
\cline { 2 - 7 } & $\mathrm{f}$ & $\%$ & $\mathrm{f}$ & $\%$ & $\mathrm{f}$ & $\%$ & \\
\hline Young age & 28 & 37.33 & 10 & 13.33 & 12 & 16.00 & $\mathbf{5 0}$ \\
\hline Middle age & 8 & 10.67 & 6 & 8 & 4 & 5.33 & $\mathbf{1 8}$ \\
\hline Old age & 1 & 1.33 & 1 & 1.33 & 5 & 6.67 & $\mathbf{7}$ \\
\hline Total & $\mathbf{3 7}$ & $\mathbf{4 9 . 3 3}$ & $\mathbf{1 7}$ & $\mathbf{2 2 . 6 6}$ & $\mathbf{2 1}$ & $\mathbf{2 8}$ & $\mathbf{7 5}$ \\
\hline
\end{tabular}

Table.8 Comparison between male and female on the basis of their age and Problems faced in using ICT tools

\begin{tabular}{|c|c|c|c|c|c|c|}
\hline \multirow{3}{*}{ Category } & \multicolumn{6}{|c|}{ Problems faced in using ICT tools } \\
\hline & \multicolumn{3}{|c|}{ Male } & \multicolumn{3}{|c|}{ Female } \\
\hline & Low & Medium & High & Low & Medium & High \\
\hline Young age & 41.33 & 14.67 & 10.67 & 37.33 & 13.33 & 16.00 \\
\hline Middle age & 12.00 & 6.67 & 5.33 & 10.67 & 8 & 5.33 \\
\hline Old age & 1.33 & 2.67 & 5.33 & 1.33 & 1.33 & 6.67 \\
\hline Total & 54.67 & 24.00 & 21.33 & 49.33 & 22.66 & 28 \\
\hline
\end{tabular}


The data of Table 6 show that out of the total respondents of young age group 10.67 per cent were facing high problem in using ICT tools followed by 14.67 per cent medium and 41.33 per cent low problem in using ICT tool and young aged group were facing problem due financial problem, ownership by other family member or restriction by other family members. Similarly, in middle age group, 5.33 per cent were facing high problem in using ICT tools followed by 6.67 per cent medium and 12.0 percent were facing low problem in using ICT tools. Middle aged group were facing problem due to either financial problem or lack of knowledge. Further, out of the total 7 respondents of old age group 5.33 per cent were facing high problem in using ICT tools followed by 2.67 per cent medium and 1.33 per cent were facing more problem in using ICT tools. Old aged group were facing problem due to either financial problem or lack of knowledge. Therefore, it can be concluded that the highest percentage of problem faced in using ICT tools were found in old age group. The finding finds support with the work of Tata and Paul (2016).

The data of Table 7 shows that out of the total respondents of young age group 16.0 per cent were facing high problem in using ICT tools followed by 13.33 per cent medium and 37.33 per cent low problem in using ICT tool. Young aged group were facing problem due financial problem, ownership by other family member or restriction by other family members. Similarly, in middle age group, 5.33 per cent were facing high problem in using ICT tools followed by 8 per cent medium and 10.67 per cent were facing low problem in using ICT tools. Middle aged group were facing problem due to their busyness in household work or lack of knowledge. Further, Further, out of the total 7 respondents of old age group 6.67 per cent were facing more problem in using ICT tools followed by 1.33 per cent medium and 1.33 per cent were facing high problem in using ICT tools. Old age group were facing problem due to either financial problem or lack of knowledge. Therefore, it can be concluded that the highest per cent of problem faced in using ICT tools were found in old age group. The finding finds support with the work of Ojokoh et al., (2013) and Tata and Paul (2016).

Young aged group of female were facing more problems in comparison to male in access to ICT tools, financial problem, Ownership by other family member or restriction by other family members to use ICT tools, because in family generally boys are preferred in providing ICT tools (Table 8). Old age female were facing more financial problem than male because they generally dependent on husband of son. These figure shows that Out of the total respondent $(\mathrm{N}=150)$ of male $(\mathrm{n}=75)$ and female $(n=75)$, female were facing more problem (28\%) in accessibility and use of ICT tools in comparison to male (21.33\%). Therefore, it can be concluded that female were facing more problems in accessibility and use of ICT tools in comparison to male. The finding finds support with the work of Tata and Paul (2016).

Majority of male and female respondents i.e. 66.66 per cent were from young age group (up to 35 year). Such finding might be due to the reason that young people participants of elearning programme were from young age group and they were more active in access and use of ICT tools. The finding finds support with the work of Haseloff (2005).

\section{References}

Drori, G. S. and Suk, J. Y (2003). The global digital divide: A sociological assessment of trends and causes. Social Science Computer Review, 21(2): 144161.

World Bank (2004) 
Haseloff, A. M. (2005). Cybercafes and their Potential as Community Development Tools in India. The Journal of Community Informatics.

Agwu A. E., Uche-Mba, U. C. and Akinnagbe, O. M. (2008) Use of Information and Communication Technologies (ICTs) among Researchers, Extension Workers and Farmers in Abia and Enugu States: Implications for a National Agricultural Extension Policy on ICTs States: Implications for a National Agricultural Extension Policy on ICTs, Journal of Agriculture Extension, 2(1).

Okiy B. R. and Ogbomo, E. F. (2011) "Supporting Rural Women's use of Information and Communication Technologies", Journal of Information Technology Impact, 11(1): 71-84.

Krubu, D. E. and Osawaru, K. E. (2011) The Impact of Information and Communication Technology (ICT) in Nigerian University Libraries, Library Philosophy and Practice.

Sulaman, R., Hall, A., Kalaivani, N.J., Dorai,
K. and Reddy, T.S.V. (2011) Necessary but not sufficient: Information and communication technology and its role in putting research into use, Research into Use Discussion Paper, Department for International Development.

Nyamba, S. Y. and Mlozi, M. R. (2012) Factors influencing the use of mobile phones in communicating agricultural information: a case of Kilolo district, Iringa, Tanzania. International Journal of Information and Communication Technology Research, 2(7).

Ojokoh, B., Zhang, M., Oluwadare, S. and Akintola, K. (2013) Women's Perceptions and Uses of Information and Communication Technologies in Nigeria and China: A Comparative Analysis, Information Management and Business Review, 5(4): 203-216.

Tata, J. S. and Namara, P. E. (2016) Social Factors That Influence Use of ICT in Agricultural Extension in Southern Africa, Agriculture open access journal MDPI, 1-10.

\section{How to cite this article:}

Meena, G. P. and Meena, R. L. 2019. Relationship between Gender Age and Extent Awareness, Knowledge about ICT Tools and Problems Faced in Access and using ICT tools. Int.J.Curr.Microbiol.App.Sci. 8(12): 389-395. doi: https://doi.org/10.20546/ijcmas.2019.812.052 